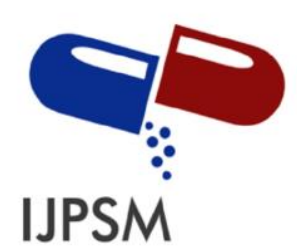

Ijazati Alfitroh et al, International Journal of Pharmaceutical Sciences and Medicine (IJPSM),

Vol.6 Issue. 7, July- 2021, pg. 153-163

ISSN: 2519-9889

Impact Factor: 3.426

\title{
Phytochemical Test of Bitter Melon (Momordica charantia L) Herb and its Effect on Rat Blood Sugar Levels
}

\author{
Ijazati Alfitroh $^{1}$; Suhatri $^{1}$; Harrizul Rivai ${ }^{{ }^{*}}$ \\ Faculty of Pharmacy, Andalas University, Limau Manih Campus, Padang 25163, Indonesia \\ "Email: harrizul@yahoo.co.id and harrizul@ phar.unand.ac.id \\ DOI: 10.47760/ijpsm.2021.v06i07.010
}

\begin{abstract}
This study aims to determine the class of chemical compounds, phytochemical levels, antihyperglycemic effects, and histopathology of the pancreas of rats treated with bitter gourd (Momordica charantia L) for the treatment of diabetes mellitus. Bitter gourd is made by adding water, then mashed and squeezed. The ingredients were tested for their phytochemical content and antidiabetic power. 15 male rats were divided into 5 groups. Group 1 as a negative control, namely normal rats without treatment, group 2 as a positive control given alloxan, group 3, namely rats given alloxan and bitter melon fruit $0.9 \mathrm{~mL}$, group 4, namely rats given alloxan and bitter melon ingredients $1.8 \mathrm{~mL}$, and group 5, namely rats, were given alloxan and a mixture of bitter melon $3.6 \mathrm{~mL}$. The phytochemical test results of bitter melon fruit contain carbohydrates, alkaloids, saponins, and terpenoids. The total alkaloid content of the bitter melon fruit is $0.232 \%$, the saponin content of the bitter melon fruit is $0.6375 \%$, and the terpenoid content of the bitter melon fruit is $0.5317 \%$. The administration of bitter melon fruit to diabetic rats can reduce blood sugar levels of rats and the histopathological observations of the pancreas of rats show a repair effect on pancreatic damage after administration of bitter melon herb.
\end{abstract}

Keywords: bitter melon ingredients, alloxan, blood sugar, histopathology.

\section{Introduction}

Indonesian people have long used traditional medicinal ingredients as an effort to maintain health, prevent disease, and treat health. Traditional Indonesian medicinal ingredients can come from plants, animals, and minerals, but generally those used are from plants [1]. According to the Decree of the Minister of Health of the Republic of Indonesia in 2017, traditional medicinal ingredients are one or more types of plants with other additives that are inert/neutral. Traditional medicine is a hereditary heritage that must be developed and researched so that it can be used as best as possible to help reduce health complaints/disorders and improve public services. Besides that, traditional medicines are also cheaper and safer [2]. That the bitter melon herb is used for diabetes [1]. 


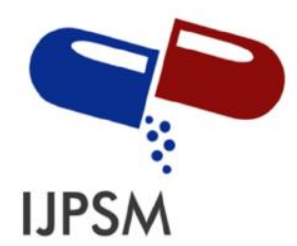

ljazati Alfitroh et al, International Journal of Pharmaceutical Sciences and Medicine (IJPSM), Vol.6 Issue. 7, July- 2021, pg. 153-163

ISSN: 2519-9889

Impact Factor: 3.426

Diabetes mellitus which in medical terms is called Diabetes Mellitus (DM) is a disease due to metabolic disorders caused by many factors, with symptoms of high blood sugar levels and disturbances in the metabolism of carbohydrates, fats, and proteins, as a result of deficiency of insulin secretion, insulin resistance and/or glucose transporter deficiency. Diabetes mellitus occurs when the insulin produced is not sufficient to maintain blood sugar within normal limits or if the body's cells are not able to respond appropriately so that the typical complaints of Diabetes Mellitus (DM) are polyuria, pilidipsi, polyphagia, weight loss, weakness, tingling, and vision [3].

Alternative medicine has now been widely developed into traditional medicine with medicines that have been proven to have a fairly good effectiveness. At this time, many people have used herbal medicines or traditional medicines to treat a disease. One of the traditional treatments that have the potential to reduce blood glucose levels is the bitter melon fruit (Momordica charantia L). In Indonesia, bitter melon has been widely used as an herbal medicine and bitter melon is widely used to treat several diseases, one of which is diabetes [4].

Pare is a plant that grows in tropical climates such as Asia, India, East Africa, and South America. Bitter gourd contains alkaloids, steroids, proteins, phenols, and saponins. Bitter gourd also has active substances that have an antihyperglycemic effect, namely charantin, polypeptide-p [5]. Bitter gourd has other benefits as an antioxidant, antitumor, neuroprotective, anti-inflammatory and antimicrobial [6]. Bitter gourd has been shown to increase the number of beta cells in the pancreas and can increase the body's ability to produce insulin [7]. Pare is used for treatment, especially for the treatment of diabetes mellitus because the saponin content in bitter melon (Momordica charantia) has the effect of lowering blood sugar levels [8].

Traditional medicinal herbs, have been widely used to treat diseases. However, the use of these traditional medicinal herbs requires evidence of their efficacy and safety. Based on the above background, the researchers wanted to examine the chemical content, total levels and blood sugar effects of the bitter melon fruit (Momordica charantia L) for diabetes in order to standardize and see the histopathology of rat pancreas.

\section{Materials and Methods}

The equipment used are analytical scales (Presica ${ }^{\circledR}$ ), animal cages, filter paper, tissue, cotton, mice drinking containers, dropper, test tube (Iwaki), mortar and stamper, test tube rack, sonde, labels, digital tools and strips. blood glucose. UV 5010 5+ spectrophotometer (Berlin), analytical weighing (Precisa), separating funnel (Iwaki), erlenmeyer (Iwaki), measuring pipette (Iwaki), beaker glass (Iwaki), spatel (Iwaki), evaporating dish (Iwaki), rod stirrer (Iwaki), measuring cup (Iwaki), capillary tube (Iwaki), micropipette (Eppendorf), centrifuge (Nuve-NF200), oral needle (Terumo), triple balance animal scale (OHAUS®).

The materials used were fresh bitter melon (Momordica charantia L.), aquadest, alloxan (Sigma Chemical \& Co. USA), glucose reagent kit (Rajawali Nusindo), standard food for mice, 10\% glucose, acetone (Merck), absolute ethanol ( Merck), distilled water (Bratachem), concentrated sulfuric acid (Merck), iron(III) chloride (Merck), iron powder (Merck), hydrochloric acid (Merck), anhydrous acetic acid (Merck), potassium permanganate (Merck), ninhydrin (Merck), chloroform (Merck), alpha-naphthol (Merck), nitric acid (Merck), ethyl acetate (Merck), acetone (Merck), methanol (Merck), chloroform (Merck), iodine (Merck), acid phosphate (Merck), hydrochloric acid (Merck). 


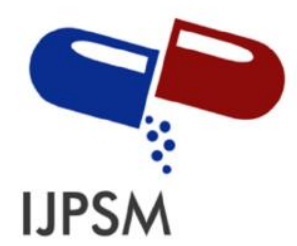

Ijazati Alfitroh et al, International Journal of Pharmaceutical Sciences and Medicine (IJPSM), Vol.6 Issue. 7, July- 2021, pg. 153-163

ISSN: 2519-9889

Impact Factor: 3.426

\section{Procedures}

\subsection{Sample preparation}

The sample used must be washed first with clean water, then cut the bitter gourd, then the sample is mashed as much as 100 grams, then add half a glass of boiled water $(100 \mathrm{~mL})$, squeeze and strain [9].

\subsection{Phytochemical Test}

Phytochemical tests were carried out to determine the content of primary and secondary metabolites contained in bitter melon water ingredients. The primary metabolites tested were carbohydrates, fats and proteins, while the secondary metabolites tested were alkaloid test, phenol test, flavonoid test, saponin test, steroid test, saponin test, tannin test, and glycoside test.

\subsection{Quantitative test}

Determination of the content of bitter melon ingredients contains carbohydrate compounds, alkaloids, saponins, and terpenoids. The next step is to test the determination of the content of each of these compounds.

1. Determination of Alkaloid Levels

Enter the $10 \mathrm{~mL}$ bitter melon mixture into the element then add $100 \mathrm{~mL}$ of methanol $\mathrm{P}$ and $10 \mathrm{~mL}$ of ammonia $\mathrm{P}$, heat over a water bath for 30 minutes, strain. Repeat 2 times the filtration using the same type and amount of solvent. Add $50 \mathrm{~mL}$ of $1 \mathrm{~N} \mathrm{LP}$ hydrochloric acid and collect the filtrate, evaporate to a volume of approximately $25 \mathrm{~mL}$, filter into a separating funnel. Base the filtrate with ammonia $\mathrm{P}$ to $\mathrm{pH} \pm 10$ using a $\mathrm{pH}$ indicator, extract 3 times with $25 \mathrm{~mL}$ of chloroform P. Collect and vaporize the chloroform phase at $50^{\circ} \mathrm{C}$, then dry at $100^{\circ} \mathrm{C}$ until the weight remains constant. Calculate the residual drying as total alkaloids [10].

\section{Determination of Saponin Levels}

A total of $50 \mathrm{~mL}$ of the dried bitter melon herb was added with $25 \mathrm{~mL}$ of $20 \%$ ethanol. The sample was heated on a magnetic stirrer for 4 hours with continuous stirring at a temperature of $55^{\circ} \mathrm{C}$. The mixture was filtered and the residue was repeated with $50 \mathrm{ml}$ of $20 \%$ ethanol. The filtrate collection was concentrated at $90^{\circ} \mathrm{C}$ to a volume of $10 \mathrm{ml}$. The concentrated filtrate was added with $5 \mathrm{~mL}$ of diethyl ether to form a diethyl ether layer. The diethyl ether layer is removed and the aqueous layer is stored. The purification is repeated. The remaining water layer was added with $15 \mathrm{~mL}$ of butanol which would form two layers. The butanol layer was deposited and the aqueous layer was filtered again with $15 \mathrm{~mL}$ butanol. The butanol group was added with $5 \mathrm{~mL}$ of $5 \%$ sodium chloride. The solution is then evaporated in a water bath. After evaporating the sample was dried in an oven to a weight [11].

\section{Determination of Terpenoid Levels}

A total of $10 \mathrm{~mL}$ of bitter melon ingredients plus $9 \mathrm{~mL}$ of $96 \%$ ethanol then put into a glass bottle, let stand for 24 hours. Strain, add $10 \mathrm{~mL}$ of petroleum ether into a separatory funnel, shake vigorously to form two layers. Take the ether separated and put into a cup. Then the ether was evaporated to dryness. The evaporated ether is the result of $\%$ of the total terpenoid content measured by the formula [12].

\subsection{Antidiabetic effect}

Before being treated, the experimental animals were acclimatized for a week by being given food and drink. Then the experimental animals to be induced diabetes were fasted for 18 hours (drinking water was still given). Then diabetes is done by giving a cold solution of alloxone interperitoneally with a dose of $100 \mathrm{mg} / \mathrm{kgBB}$. 


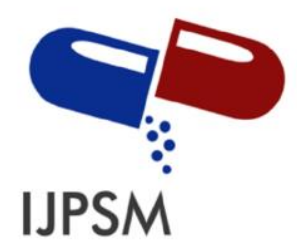

ljazati Alfitroh et al, International Journal of Pharmaceutical Sciences and Medicine (IJPSM), Vol.6 Issue. 7, July- 2021, pg. 153-163

ISSN: 2519-9889

Impact Factor: 3.426

Animals were divided into 5 groups, group 1 was a negative control, group 2 was a positive control, while the dose groups 1, 2, and 3 were given a bitter melon herb at a dose of $0.9 \mathrm{~g} / 200 \mathrm{gBB}, 1.8 \mathrm{~g} / 200 \mathrm{gBB}$, and $3.6 \mathrm{~g} / 200 \mathrm{gBB}$, dose 1 was given $0.9 \mathrm{~mL}$, dose 2 was $1.8 \mathrm{~mL}$ and dose 3 was given $3.6 \mathrm{~mL}$ (table 2). Rats that had been given alloxan were housed for two days and given a drink containing $10 \%$ glucose solution for two days after alloxan was given, each group consisted of 3 animals [13]. Blood sugar examination was carried out using a 5010 V5+ photometer. Mice were declared hyperglycemic if their blood sugar levels were $>200$ $\mathrm{mg} / \mathrm{dL}$, then rats were given bitter gourd for 21 days.

\subsection{Histopathology of the pancreas}

According to [14], the preparation of pancreatic histopathological preparations was carried out by the following procedure:

\section{a. Fixation}

Pancreas from experimental animals that have been sacrificed are taken, then the pancreas is cleaned and put into physiological $\mathrm{NaCl}$ solution for 30 minutes. Then the pancreas was immersed in a $10 \%$ neutral formalin (BNF) buffer solution for a maximum of 24 hours. Then it is done by cutting with a thickness of $\pm 3 \mathrm{~mm}$, insert it into the cassette.

b. Dehydration

The tissue in the cassette is put into a tissue processor to be dehydrated. The dehydration process was carried out using alcohol with graded concentrations consisting of 70\%, 80\%, 90\%, and 95\% alcohol, absolute alcohol for 1 hour. Then, it is cleaned by inserting the preparation into xylol. Then put into the infiltration solution carried out in an incubator at a temperature of $50-60^{\circ} \mathrm{C}$.

c. Immersion ( Embedding) and printing (Blocking)

Preparations that have been dehydrated are planted in molds that have been filled with liquid paraffin half of its volume and before freezing, liquid paraffin is added until it is full and then cooled on a cold plate. The hardened mold is removed from the mold and the obtained blocks can be stored in the refrigerator until they are ready to be cut with a microtome.

\section{d. Cutting}

Preparations in paraffin blocks were cut using a microtome knife with a thickness of $5 \mathrm{~m}$ to form a ribbon and placed on the surface of warm water to prevent creases in the tape. Then the preparation was placed on a slide and dried at room temperature. The prepared preparations were stained with hematoxylin-eosin (HE) for histopathological observation. Histopathological observations of pancreatic slides were carried out under a microscope. 


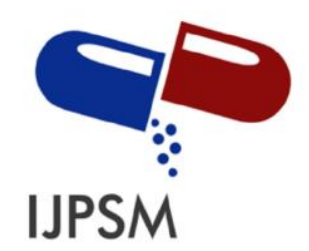

Ijazati Alfitroh et al, International Journal of Pharmaceutical Sciences and Medicine (IJPSM), Vol.6 Issue. 7, July- 2021, pg. 153-163

ISSN: 2519-9889

Impact Factor: 3.426

\section{Result and Discussion}

\subsection{Qualitative Analysis}

Seen in (table 1). Phytochemical test results from the group of compounds in bitter melon ingredients contain carbohydrates, alkaloids, terpenoids, and saponins.

Table 1. Phytochemical test results from bitter melon fruit (Momordica charantia).

\begin{tabular}{|c|c|c|}
\hline Chemical Parameter & Test & Observation \\
\hline \multirow[t]{2}{*}{ Carbohydrate } & Molish test & + \\
\hline & Fehling's test & - \\
\hline Protein & Biuret Test & _ \\
\hline Oils and Fatty Acids & Filter paper & - \\
\hline \multirow[t]{3}{*}{ Alkaloids } & Dragendorff's test & + \\
\hline & Mayer's test & + \\
\hline & Wagner test & + \\
\hline \multirow[t]{2}{*}{ Flavonoid } & Zn test & - \\
\hline & Mg test & - \\
\hline Steroids and Terpenoids & Steroid test & - \\
\hline
\end{tabular}




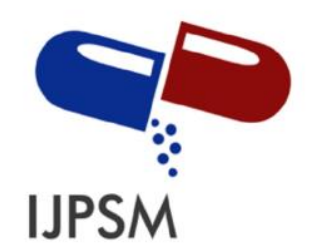

Ijazati Alfitroh et al, International Journal of Pharmaceutical Sciences and Medicine (IJPSM), Vol.6 Issue. 7, July- 2021, pg. 153-163

ISSN: 2519-9889

Impact Factor: 3.426

\begin{tabular}{|l|l|c|}
\hline & Terpenoid test & + \\
\hline Phenol & $\mathrm{FeCl}_{3}$ & - \\
\hline Tannins & & \\
& $\mathrm{FeCl}_{3}$ & - \\
\cline { 2 - 4 } & Lead Acetate Test & - \\
\hline Saponins & & + \\
\hline Glycoside & Foam Test Saponins & \\
\hline & & \\
\hline
\end{tabular}

\subsection{Quantitative Analysis}

a. Determination of Total Alkaloid Levels

Determination of total alkaloid content was done by gravimetric method. Based on the results obtained, the total alkaloid content in bitter melon ingredients is $0.232 \%$.

b. Determination of Terpenoid Levels

Determination of total terpenoid content was carried out by the gravimetric method. Based on the results obtained, the total terpenoid content in bitter melon ingredients is $0.5317 \%$

c. Determination of Saponin Levels

Determination of total saponin levels was carried out by the gravimetric method. Based on the results, the total saponin content in bitter melon fruit ingredients is $0.6385 \%$.

\subsection{Antidiabetic Test}

All test animal blood sugar data were normally distributed after being analyzed by Shapiro-Wilk ( $>0.05)$. The blood sugar of rats was significantly affected $(\mathrm{P}<0.05)$ dose, duration of administration, and interaction of dose and duration of administration of bitter melon (Momordica charantia) $(\mathrm{P}<0.05)$. Seen in (table 2$)$ and (figure 1) the positive control group, dose 1, dose 2, and dose 3 after alloxan was induced blood sugar levels increased, then after being given bitter melon concoction on days 7, 14 and 21 there was a decrease, compared to with positive control group animals after alloxan induced blood sugar levels remained high. And obtained the 


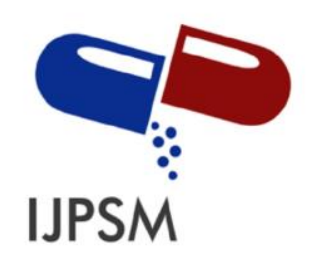

Ijazati Alfitroh et al, International Journal of Pharmaceutical Sciences and Medicine (IJPSM), Vol.6 Issue. 7, July- 2021, pg. 153-163

ISSN: 2519-9889 Impact Factor: 3.426

average blood sugar levels of negative control animals $93 \mathrm{mg} / \mathrm{dL}$, positive control group $287 \mathrm{mg} / \mathrm{dL}$, dose 1 $179 \mathrm{mg} / \mathrm{dL}$, dose $2171 \mathrm{mg} / \mathrm{dL}$, and dose $3193 \mathrm{mg} / \mathrm{dL}$, after being given a fruit herb. bitter melon on day 7 blood sugar levels $185 \mathrm{mg} / \mathrm{dL}$ lower than the positive control group $242 \mathrm{mg} / \mathrm{dL}$, then on day $14157 \mathrm{mg} / \mathrm{dL}$, and on day $21154 \mathrm{mg} / \mathrm{dL}$.

Table concoction on decreasing the average blood sugar level of rats.2. The effect of dose and duration of administration of bitter melon (Momordica charantia)

\begin{tabular}{|l|l|c|c|c|c|}
\hline $\begin{array}{l}\text { Treatment } \\
\text { Group } \\
(\mathrm{mL} / \mathrm{KgBB})\end{array}$ & \multicolumn{5}{|c|}{$\begin{array}{l}\text { Blood sugar level (mg/dL) } \\
\text { Days to }\end{array}$} \\
\hline & $\begin{array}{l}\text { After } \\
\text { Induction }\end{array}$ & 7 & 14 & 21 & $\begin{array}{l}\text { Average } \\
\pm \text { SD }\end{array}$ \\
\hline $\begin{array}{l}\text { Negative } \\
\text { control }\end{array}$ & $102 \pm 5.6$ & $97 \pm 3.8$ & $89 \pm 5.6$ & $83 \pm 5.5$ & $93 \pm 8.8^{\mathrm{a}}$ \\
\hline $\begin{array}{l}\text { Positive } \\
\text { Control }\end{array}$ & $311 \pm 25.4$ & $282 \pm 21.4$ & $244 \pm 16.0$ & $311 \pm 21.0$ & $287 \pm 33.8^{\mathrm{a}}$ \\
\hline $\begin{array}{l}1 \text { Dose } \\
(0.9 \mathrm{~mL})\end{array}$ & $234 \pm 12.4$ & $194 \pm 9.2$ & $153 \pm 5.7$ & $136 \pm 13.5$ & $179 \pm 40.6^{\mathrm{b}}$ \\
\hline $\begin{array}{l}2 \mathrm{Dose} \\
(1.8 \mathrm{~mL})\end{array}$ & $277 \pm 40.2$ & $171 \pm 29.7$ & $132 \pm 9.6$ & $106 \pm 7.1$ & $171 \pm 71.3^{\mathrm{c}}$ \\
\hline $\begin{array}{l}3 \mathrm{D} \text { Dose } \\
(3.6 \mathrm{~mL})\end{array}$ & $289 \pm 13.3$ & $183 \pm 8.0$ & $165 \pm 8.3$ & $135 \pm 6.6$ & $193 \pm 61.3^{\mathrm{d}}$ \\
\hline $\begin{array}{l}\text { Average } \\
\pm \text { SD }\end{array}$ & $242 \pm 79.2$ & $185 \pm 62.8^{\mathrm{p}}$ & $157 \pm 53.2^{\mathrm{q}}$ & $154 \pm 84.2^{\mathrm{r}}$ & \\
\hline
\end{tabular}




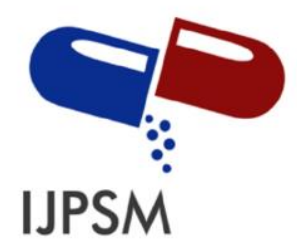

Ijazati Alfitroh et al, International Journal of Pharmaceutical Sciences and Medicine (IJPSM), Vol.6 Issue. 7, July- 2021, pg. 153-163

ISSN: 2519-9889

Impact Factor: 3.426

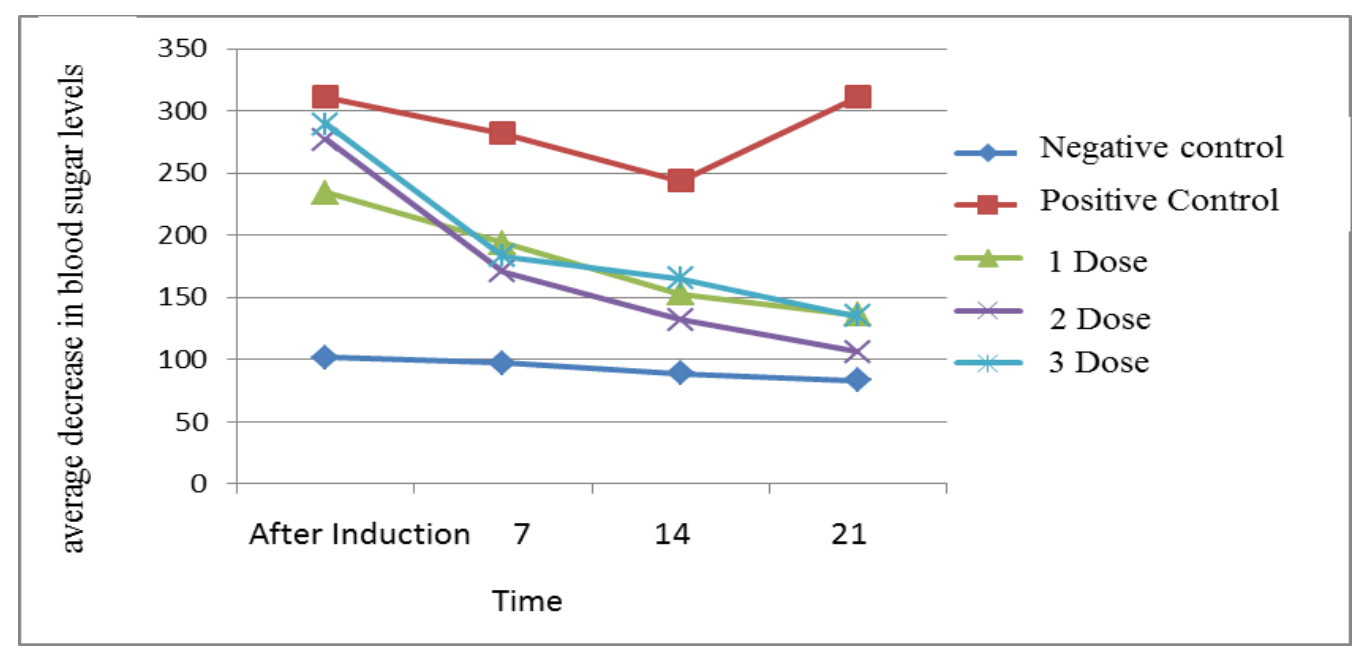

Figure 1. Graph of the effect of dose and duration of administration of bitter melon concoction on decreasing average blood sugar levels.

The results showed that after being analyzed using the two-way ANOVA test that the data on blood sugar levels of the test animals were normally distributed after being analyzed by Shapiro-Wilk ( $P>0.05)$. The blood sugar level of rats is influenced by dose, duration of administration and dose interaction. Significantly $(\mathrm{P}<0.05)$ the dose variation had an effect on reducing blood sugar levels of rats after being given the bitter melon fruit juice, the duration of administration could also significantly decrease the effect of reducing blood sugar levels in rats after being given the bitter melon juice, and the interaction of dose and duration variations administration also gave a greater effect on reducing blood sugar levels in rats. The higher the dose and the longer the administration, the greater the decrease in blood sugar.

In this study, alloxan was also used as an inducer of diabetes mellitus. Alloxan is used as an antidiabetic agent. Administration of alloxan has an effect on the degradation of beta cells in the islets of Langerhans, the organ responsible for making insulin in the body. The mechanism of action of alloxan in destroying beta cells of the islets of Langerhans is still controversial. Several hypotheses regarding the mechanism of action of alloxan as a diabetogen include the mechanism of formation of chelates against $\mathrm{Zn}$ and affecting beta cell enzymes resulting in deamination and decarboxylation of amino acids. As a result, insulin production is insufficient so that glucose levels in the blood increase [11].

Based on the research that has been done, the administration of bitter melon juice (Momordica charantia) has a significant effect on lowering blood glucose levels. In a study conducted by [16] bitter melon contains saponins, flavonoids, terpenoids, steroids, proteins and steroids. Another study [1]. Reported that bitter melon contains alkaloids, phenolic compounds, saponins, fatty acids, proteins and flavonoids. In this research, it was found that bitter melon fruit juice (Momordica charantia) contains carbohydrate compounds, alkaloids, saponins, terpenoids. Allegedly because some of these secondary metabolites have a synergistic performance in reducing glucose levels. It is suspected that bitter melon can stimulate the repair of beta cells, so that it can increase the insulin production process, as well as increase glucose secretion. Saponins can reduce blood glucose levels by increasing insulin secretion in pancreatic beta cells, increasing glucose uptake in the small intestine. Saponins can reduce the increase in blood glucose by inhibiting the amylase enzyme breaking down 


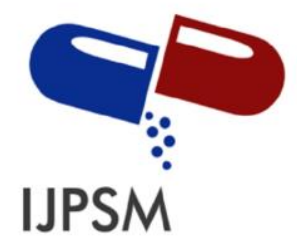

ljazati Alfitroh et al, International Journal of Pharmaceutical Sciences and Medicine (IJPSM), Vol.6 Issue. 7, July- 2021, pg. 153-163

ISSN: 2519-9889

Impact Factor: 3.426

disaccharides into monosaccharides, promoting glycogen storage by the liver and insulin secretion by the islets of Langerhans [17].

The alkaloid content has the ability to inhibit the action of the -glucosidase enzyme [18] Alkaloids are believed to have the ability to regenerate damaged pancreatic beta cells. Antioxidant activity is able to capture free radicals that cause damage to pancreatic beta cells that cause DM. There is an improvement in pancreatic tissue, then there is an increase in the amount of insulin in the body so that blood glucose will enter the cells and there will be a decrease in blood glucose levels [19]. The content of terpenoids has potential in the treatment of diabetes. namely, inhibition of carbohydrate metabolism enzymes, reduction of blood glucose, and reduction of oxidative stress [20].

\subsection{Pancreatic histopathological test}

When viewed from the histopathological description of the administration of bitter melon ingredients, it showed that there was a histopathological improvement of the damaged pancreatic tissue of experimental animals after being induced with alloxan. A normal pancreas appears with an exocrine gland component consisting of a tubular structure with cuboidal cells, and a lumen in the middle. The endocrine component is the islets of Langerhans with fine granular cytoplasmic round cells (figure 2).

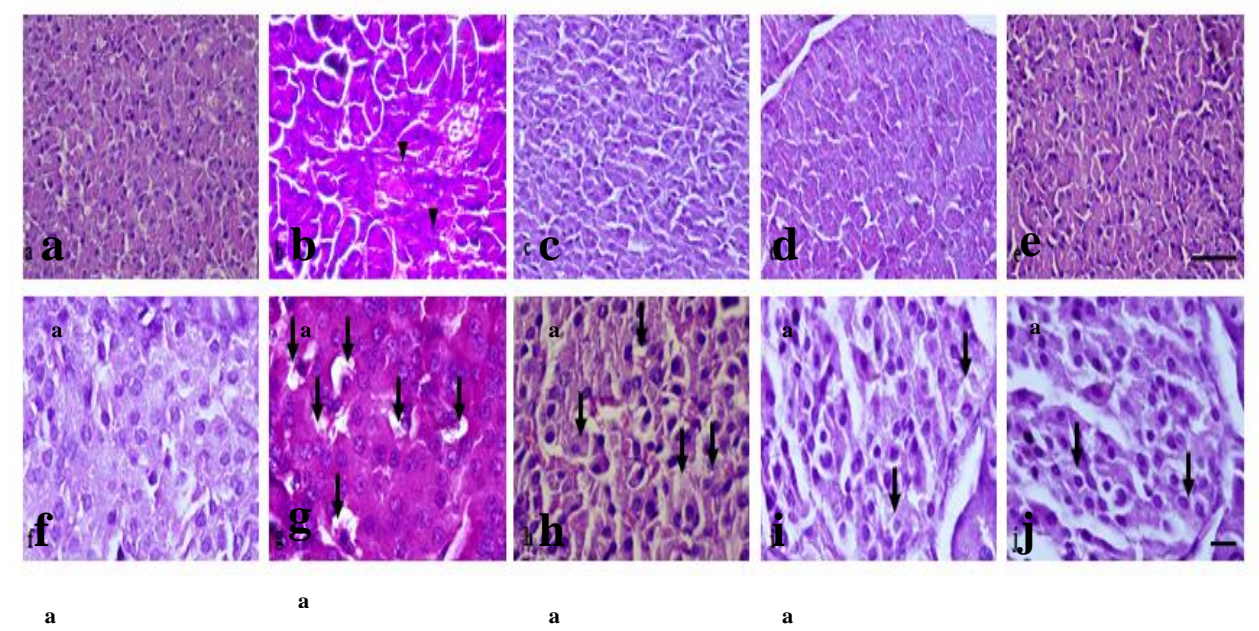

Figure 2. Histopathology of rat pancreatic tissue

Notes: negative control (a, f), alloxan induction $(b, g)$, treatment dose $1(\mathrm{c}, \mathrm{h})$, treatment dose $2(\mathrm{~d}, \mathrm{i})$ and treatment dose $3(e, j)$.

The pancreas of animals in positive controls that were given alloxan showed exocrine glands, some of which showed signs of mild to moderate inflammation, neutrophil cells and connective tissue experienced mild fibrosis and edema (congestion). Endocrine tissue with several cytoplasmic vacuolated cells. Part of the nucleus that is difficult to see and the nuclear membrane is blurred as a sign of cell degeneration. It is difficult to assess the cell type on Hematoxylin-eosin staining. The presence of mild fibrosis in the administration of alloxan which is only given for a short period of time causes temporary inflammation, mild inflammation occurs, the fibrosis is also mild because in principle it only disrupts the endocrine system.

The administration of bitter melon concoction to alloxan-treated rats showed that the number of endocrine cells in the islets of Langerhans that were degenerated (damaged) was lower than the positive control. However, 


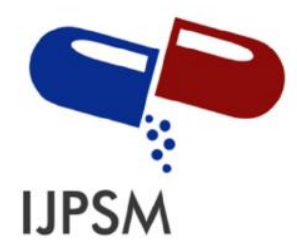

Ijazati Alfitroh et al, International Journal of Pharmaceutical Sciences and Medicine (IJPSM), Vol.6 Issue. 7, July- 2021, pg. 153-163

ISSN: 2519-9889

Impact Factor: 3.426

there were still some cells with signs of degeneration at the three treatment doses. When compared between treatment doses 1 to 3 , there was not much difference in the proportion of degenerated cells, although when compared to the positive control, the difference was quite clear. There was no clear difference in the number of degenerated cells between the three doses, but there was an impression at medium and high doses on the histopathological picture.

It is difficult to distinguish the proportion of pancreatic cell damage in the assessment with hematoxylin and eosin staining accurately between each treatment level of bitter melon fruit because the assessment with hematoxylin-eosin staining is less sensitive in detecting endocrine cell degeneration, and is not a specific stain [21].

\section{Conclusion}

Based on qualitative, quantitative analysis, the effect of bitter melon herb on the reduction of blood sugar levels and pancreatic histopathology of bitter melon fruit (Momordica charantia) and concluded that:

1. The herb bitter melon (Momordica charantia) contains a class of carbohydrate compounds, alkaloids, terpenoids and saponins.

2. The total alkaloid content of the bitter melon fruit (Momordica charantia) is $0.232 \%$, the total terpenoid content of the bitter melon fruit (Momordica charantia) is $0.5317 \%$, and the total saponin content of the bitter melon fruit (Momordica charantia) is $0.6385 \%$.

3. There is an effect of dose and duration of administration in reducing blood sugar levels of rats after administration of bitter melon fruit (Momordica charantia) concoction.

4. The results of histopathological observations of rat pancreas showed a repair effect on pancreatic damage after administration of bitter melon fruit (Momordica charantia) both on exocrine and endocrine components.

\section{References}

[1]. Indonesia DR. Indonesian Traditional Medicine Formulary. Jakarta. Ministry of Health RI. 2017.

[2]. Dalimartha S. Traditional Herbs for the Treatment of Diabetes Mellitus. Self-Help Disseminator; 2005.

[3]. Soegondo S, Soewondo PS. I. Integrated Diabetes Management. Jakarta: FKUI Publishing Center. 2009.

[4]. Subahar T. Efficacy and Benefits of Pare, the Bitter Disease Control: Agromedia Pustaka. 2004.

[5]. Joseph B, Jini D. Antidiabetic effects of Momordica charantia (bitter melon) and its medicinal potency. Asian pacific journal of tropical disease. 2013 Apr 1;3(2):93-102.

[6]. Nkambo W, Anyama NG, Onegi B. In vivo hypoglycemic effect of methanolic fruit extract of Momordica charantia L. African health sciences. 2013;13(4):933-9.

[7]. Shetty AK, Kumar GS, Sambaiah K, Salimath PV. Effect of bitter gourd (Momordica charantia) on glycaemic status in streptozotocin induced diabetic rats. Plant Foods for Human Nutrition. 2005 Sep 1;60(3):109-12.

[8]. Oishi Y, Sakamoto T, Udagawa H, Taniguchi H, Kobayashi-Hattori K, Ozawa Y, Takita T. Inhibition of increases in blood glucose and serum neutral fat by Momordica charantia saponin fraction. Bioscience, biotechnology, and biochemistry. 2007 Mar 23;71(3):735-40.

[9]. Indonesia DR. Indonesian Traditional Medicine Formulary. Jakarta. Ministry of Health RI. 2017.

[10].Indonesia DR. Indonesian Herbal Pharmacopoeia. Edition I. Jakarta: Ministry of Health RI. 2008. 


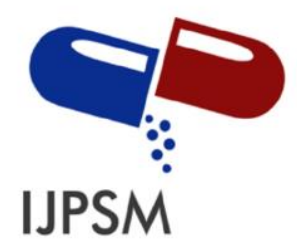

Ijazati Alfitroh et al, International Journal of Pharmaceutical Sciences and Medicine (IJPSM), Vol.6 Issue. 7, July- 2021, pg. 153-163

ISSN: 2519-9889

Impact Factor: 3.426

[11].Ajiboye BO, Ibukun EO, Edobor G, Ojo AO, Onikanni SA. Qualitative and quantitative analysis of phytochemicals in Senecio biafrae leaf. International Journal of Inventions in Pharmaceutical Sciences. 2013;1(5):428-32.

[12].Malik SK, Ahmad M, Khan F. Qualtitative and quantitative estimation of terpenoid contents in some important plants of punjab, pakistan. Pakistan Journal of Science. 2017 Jun 1;69(2):150.

[13].Lenzen S. The mechanisms of alloxan-and streptozotocin-induced diabetes. Diabetologia. 2008 Feb;51(2):216-26.

[14]. Mescher AL, Junqueira S. Basic histology text and atlas.

[15]. Daniel P, Supe U, Roymon MG. A review on phytochemical analysis of Momordica charantia. Int. J. Adv. Pharm. Biol. Chem. 2014;3(1).

[16]. Ahmad N, Hasan N, Ahmad Z, Zishan M, Zohrameena S. Momordica charantia: for traditional uses and pharmacological actions. Journal of Drug Delivery and Therapeutics. 2016 Mar 14;6(2):40-4.

[17].Zhu Y, Dong Y, Qian X, Cui F, Guo Q, Zhou X, Wang Y, Zhang Y, Xiong Z. Effect of superfine grinding on antidiabetic activity of bitter melon powder. International Journal of Molecular Sciences. 2012 Nov;13(11):14203-18.

[18].Patel S, Patel T, Parmar K, Bhatt Y, Patel Y, Patel NM. Isolation, characterization and antimicrobial activity of charantin from Momordica charantia linn. Fruit. Int J Drug Dev Res. 2010;2(3):629-34.

[19].Tandi J. Effect of Ethanol Extract Gendola Leaf Leaf (Basella alba L.) on Decreasing Blood Glucose Condition and Histopatology Pankreas White Rats (Rattus norvegicus) Indicated Streptozotocin. JIMR-Journal of Islamic Medicine Research. 2017 Dec 1;1(2).

[20].Panigrahy SK, Bhatt R, Kumar A. Targeting type II diabetes with plant terpenes: the new and promising antidiabetic therapeutics. Biologia. 2021 Jan;76(1):241-54.

[21].Musumeci G. Past, present and future: overview on histology and histopathology. Journal of Histology and Histopathology. 2014;1(1):5.

\section{Acknowledgement}

The researcher would like to thank the Dean of the Faculty of Pharmacy, Andalas University, who has given permission to research and use the equipment at the Pharmacology Laboratory, Faculty of Pharmacy, Andalas University, Padang.

\section{A Brief Author Biography}

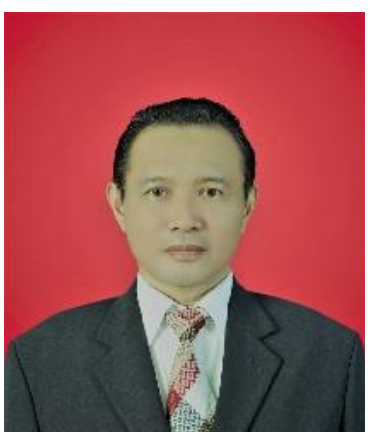

Prof. Dr. Harrizul Rivai, M.S. was born in Payakumbuh, West Sumatra, on 4 September 1953. His father is Rivai Said, and his mother is Saridahanum Syofyan. The Author obtained a Bachelor of Pharmacy from the Department of Pharmacy, Faculty of Mathematics and Natural Sciences, Padjajaran University, Bandung (1976), a Master of Science degree from the Bandung Institute of Technology (1984), and a Doctorate from the Department of Chemistry, Faculty of Mathematics and Natural Sciences, Andalas University, Padang (2011). Now the Author is a Professor and Researcher at the Faculty of Pharmacy, Andalas University, Padang. The Author also serves as Deputy Chair of Academic Affairs at the YPTIK Padang College of Pharmacy (STIFARM). The Author wrote the book "Principles of Chemical Examination" (Publisher UI-Press, 1995), translated the book "Pharmaceutical Statistics" (EGC Medical Book Publishers, 2010), and wrote "Chapter 4" in the book "Recent Research Advances in Biology Vol. 4" (Book Publisher International, India, and United Kingdom, 2020), and wrote the book "Chinese Petai (Leucaena leucocephala): Traditional Uses, Phytochemicals, and Pharmacological Activities" (Deepublish, Yogyakarta, 2021). He wrote - Chapter 9\| in the book - Recent Research Advances in Biology Vol. 7" and -Chapters 5, 6, 7, and 8\| in the book - Technological Innovation in Pharmaceutical Research Vol. 3 (Book Publisher International, India, and United Kingdom, 2021). The Author has also written articles in various international journals in various science fields, such as chemistry, biology, and pharmacy. 